\title{
The Relationship between Optimism, Pre-Entrepreneurial Curiosity and Entrepreneurial Curiosity
}

\author{
Mitja Jeraj
}

JPO d.o.o., Kobetova 22, 1000 Ljubljana, mijeen@gmail.com

Background: Entrepreneurship and entrepreneurs become more and more interesting fields for a scientific research. This paper addresses the relationship between optimism, pre-entrepreneurial curiosity and entrepreneurial curiosity as three determinants of entrepreneurial psychology. Literature review showed optimism is important for entrepreneurs and influence them mostly in a positive way. Although entrepreneurial curiosity is important determinant for entrepreneurs and it was connected with entrepreneurial self-efficacy, openness, and company's growth the connection with optimism remained unexplored until this research.

Methods: A multi-country empirical validation was conducted on a sample of entrepreneurs from Slovenia and USA. A structural equation modelling, exploratory factor analysis (EFA) and confirmatory factor analysis (CFA) were used to develop a model, which complement theoretical predisposition and fit the data.

Results: The results of the study show that higher levels of optimism lead to higher levels of pre-entrepreneurial curiosity and higher levels of pre-entrepreneurial curiosity lead to higher levels of entrepreneurial curiosity.

Conclusions: The contribution of this study is manifold. From the theoretical view, a literature gap on the field of optimism and entrepreneurial curiosity combined is fulfilled and a structural equation model with optimism and entrepreneurial curiosity was established. Since openness, pre-entrepreneurial curiosity and entrepreneurial curiosity are related policy makers can test individuals according to their level of researched determinants and motivate more entrepreneurial perspective ones to become active in the entrepreneurship process. Thus, entrepreneurs can use these results to recruit more entrepreneurial oriented employees.

Keywords: Optimism; Entrepreneurial Curiosity; Pre-Entrepreneurial Curiosity; Entrepreneurship; Entrepreneur.

\section{Introduction}

Entrepreneurship matters. Although entrepreneurship in the informal economy receives very little attention in academic literature, there are several reasons why it cannot be ignored (Thai and Turkina, 2013). Beside entrepreneurship is the most powerful economic force known to humankind (Kuratko, 2013) it positively influences reduction of unemployment and contributes to GDP. The complex of entrepreneurship domain integrates many different but connected fields. The varied definitions in entrepreneurship literature reflect this complexity (Autio, 2007). However, the research on entrepreneurship and small businesses has started attracting the interest of scholars and policy makers and the importance of small and medium-sized enterprises is increasingly acknowledged in Academia as well as in the public debate (Ulhøi, 2005).

In today's world small business, and particularly new ones, are seen more than ever as a vehicle for entrepreneurship, contributing not just to employment and social and political stability, but also to innovative and competitive power (Wennekers and Thurik, 1999). Audretsch et al. (2001) argued that on the one hand, high unemployment rates may lead to start-up activity of self-employed individu-

Received: $2^{\text {nd }}$ April 2013; revised: $19^{\text {th }}$ June 2014; accepted; July $17^{\text {th }}, 2014$ 
als (the "refugee" effect) and on the other hand, higher rates of self-employment may indicate increased entrepreneurial activity reducing unemployment in subsequent periods (the "entrepreneurial" effect). Since entrepreneurial activity is increasingly relevant to economic and labor employment in both developed and developing nations, new knowledge about entrepreneurship can speed the outcomes desired by enterprising individuals, firms, and societies (Busenitz et al., 2003).

Entrepreneurs often play vital roles in the early evolution of industries, examples of such (successful American) entrepreneurs include Andrew Carnegie, Michael Dell, Thomas Edison, Henry Ford, Bill Gates, Ray Kroc, and Sam Walton (Van Stel et al., 2005). The entrepreneur is not a fixed state of existence; rather entrepreneurship is a role that individuals undertake to create organizations (Gartner, 1988). Thus Henderson and Robertson (2000) suggest that the traditional view of the entrepreneur is as a »risk-taker« bringing different factors of production together.

There are many reasons why individuals decide to become entrepreneurs. For most management scholars and some psychologists, the difference lies less in attitudes toward risk than in the perception of risk: entrepreneurs typically overestimate the chances that their project will be successful (Pinfold, 2001). In this manner the strongest source of entrepreneurial optimism is likely to be selection combined with representativeness: people don't become entrepreneurs by accident but because they perceive that they have a project that dominates their other career choices although entrepreneurial projects are typically highly uncertain; because of their novelty, there is very little evidence on which to base future expectations (Landier and Thesmar, 2009). Thus recent studies on the field of entrepreneurial psychology show that also entrepreneurial curiosity (Jeraj and Marič, 2013a) is a good predictor for entrepreneurial intentions. This paper establishes a theoretical and empirical relation between two important psychological determinants influencing entrepreneurs in their professional life. Those determinants are optimism and entrepreneurial curiosity.

\section{Influences on the entrepreneurship}

Many factors influence entrepreneurs. Literature review from the field of entrepreneurship, management, organizational sciences, psychology and sociology revealed that researchers studied different aspects of entrepreneurship as: entrepreneurial intentions (Douglas, 2012); entrepreneurial motivation (Shane et al., 2003), entrepreneurial creativity (Amabile, 1997); family of entrepreneurs (Dyer and Handler, 1994); environment (York and Venkataraman, 2010); and other entrepreneurial related fields.

In line with diversified research on the field of entrepreneurs as written above it was found that many different factors influence entrepreneurship as a broader research discipline. For example, Dees (1998) researched the influ- ence of social factors on entrepreneurship; Kreft and Sobel (2005) connected entrepreneurship with economic freedom; Doepke and Zilibotti (2013) founded the relation between culture and entrepreneurship; Román et al. (2013) argued that economic situation influence entrepreneurship; and others.

Different determinants influence entrepreneurs; they have different education, come from different environment, operate on different markets, and others. The fact is that starting a business is a very risky choice: depending on the country, between $40 \%$ and $60 \%$ of newly created firms die before their fourth birthday (Landier and Thesmar, 2009; Scarpetta et al., 2002). In spite of those facts, there are still individuals who become entrepreneurs and risk their money, time, and good name in relation to the thin line between success and fail.

Several authors claimed that optimism was associated with positive outcomes of entrepreneurship, success of entrepreneurs, and their contributions to the economies in which they operate. On the one hand, researchers in psychology have investigated optimism as an attribute of individuals that governs positive thinking and the outlook of the future, and perhaps relates to better outcomes, better performance, better personal well-being, and coping strategy (Liang and Dunn, 2010). On the other hand, Renner (2006) claimed curiosity refers to the desire to acquire new information. Thus, to be successful, entrepreneurs must be curious about different specific entrepreneurial-related topics (Jeraj and Antončič, 2013). Since entrepreneurs need many different data about market, marketing, HRM, different regulations, tax demands and others, it is necessary to gather this information and make the right business decisions in order to be successful on the long term. Base on that facts optimism and entrepreneurial curiosity are important determinants, which influence entrepreneurs.

Sarasvathy et al. (2013) find out according to a detailed review of four literatures, namely, (1) Industrial organization, (2) Population ecology, (3) Labor and microeconomics, and (4) Entrepreneurship, that entrepreneurial performance is usually confounded with firm performance. The positive and statistically robust link between entrepreneurship and economic growth has now been verified across a wide spectrum of units of observation, the enterprise, the industry, the region, and the country (Thurik and Wennekers, 2004). Thus, as suggested by Jeraj and Antončič (2013) motivated individuals with a relatively high level of entrepreneurial curiosity could be involved in the entrepreneurial process and contribute to the innovativeness and growth of the company.

\section{Optimism and entrepreneurship}

Many scholars studied how optimism influences people in different occasions (e.g. Wenglert and Rosén, 2000; Orejudo et al., 2012; Chang and Farrehi, 2001). Scheier et al. (1994) described optimists in general as people who tend to hold 
positive expectancies for their future. Optimism, conceptualized and assessed in a variety of ways, has been linked to positive mood and good morale; to perseverance and effective problem solving; to academic, athletic, military, occupational, and political success; to popularity; to good health; and even to long life and freedom from trauma (Peterson, 2000). Accumulating evidence from variety of sources suggest that dispositional optimism is beneficial for physical and psychological well-being (Scheier et al., 1994). Furthermore, optimism has been linked also to entrepreneurs.

Bengtsson and Ekeblom (2014) suggested, based on existing empirical evidence that entrepreneurs are optimists, a finding researchers often interpret as evidence of a behavioral bias in entrepreneurial decision-making. Further several empirical papers have tested the expectation that entrepreneurs are optimists (Bengtsson and Ekeblom, 2014; Cooper, Woo and Dunkelberg, 1988; Busenitz and Barney, 1997; Camerer and Lovallo, 1999; Arabsheibani et al., 2000; Fraser and Greene, 2006; Puri and Robinson, 2006; Koellinger, 2008; Crane and Crane, 2007; Trevelyan, 2008; Ucbasaran et al., 2010; Cassar, 2010 etc.) and the main finding from existing works is that entrepreneurs hold beliefs about their own life or work.

Dushnitsky (2010) wrote different authors conjecture that individual disposition offers one viable explanation: entrepreneurship is attractive if individuals are optimistic about the probability of their survival. Literature has also discussed optimism and its relationship to other entrepreneurial characteristics, how optimism impacts on venture performance (success and failure) and decision making, and different levels of unrealistic optimism leading to various consequences in venture development (Schneider, 2005; Liang and Dunn, 2008a; Liang and Dunn, 2008b; Liang and Dunn (2010)). On the other hand, James and Gudmundsson (2012) stressed that the generally perceived positive emotions of passion and high levels of dispositional optimism within the entrepreneur pose a tension, and are potentially both a benefit and a burden for entrepreneurial success. Base on that it is positive for entrepreneurs to have optimism to be successful but it should not be a prevailing determinant to avoid negative consequences.

Therefore, positive psychological emotions such as optimism may be critical in providing the motivating behaviour to enable the individual entrepreneur to persist through the opportunity discovery, evaluation and exploitation phases of the new venture process (James and Gudmundsson, 2012). Question that appears here is if optimism is positive also for stimulating entrepreneurial curiosity.

\section{Entrepreneurial curiosity and optimism}

Entrepreneurial curiosity is a positive emotional/motivational system oriented toward investigation in the entrepre- neurial framework to learn tasks related to entrepreneurship and incorporate new experiences in order to improve business (Jeraj, 2012; Jeraj and Antončič, 2013; Jeraj and Marič, 2013b). Entrepreneurial curiosity is an interest in novelties or observations of society and a tendency to search for answers that indicate which demands should be met and it represents guidance and competitive advantages for entrepreneurs relative to the competition (Jeraj and Marič, 2013a). Entrepreneurial curiosity is awake, when an entrepreneur is facing different stimulus related to the entrepreneurship in the environment (Jeraj and Prodan 2010).

Literature review revealed that entrepreneurial curiosity was connected with some determinants from the field of entrepreneurship. Study of entrepreneurial curiosity (Jeraj, 2014) conducted on a sample of entrepreneurs from Slovenia and USA showed that entrepreneurial curiosity was linked with openness and company's growth. The results of the study indicated that the higher level of openness leads to higher entrepreneurial curiosity and the higher levels of entrepreneurial curiosity effects the company's growth.

Another study of Jeraj and Marič (2013a) indicated positive relationship between entrepreneurial curiosity and entrepreneurial self-efficacy measured on an international sample of entrepreneurs from Slovenia and USA, where was entrepreneurial curiosity, as also entrepreneurial selfefficacy a good predictor for entrepreneurial intentions. Further, on the one hand Luthans and Youssef (2004) suggest that individuals possessing the combination of selfefficacy, optimism, hope, and resiliency tend to be endowed with high levels of psychological capital, on the other hand Jensen and Luthans (2006) studied the link between entrepreneurs' positive psychological capital and leadership approach (Černe et al., 2013; Marič et al., 2013), which was found as grounded.

Since entrepreneurs are one of the most important elements for the success of their companies and since the literature review revealed that both, optimism and entrepreneurial curiosity are important determinants influencing entrepreneurs it is necessary to empirically test the relation between these two entrepreneurial-psychological factors.

Based on findings from the literature review, the following hypotheses were formulated:

Hypothesis 1: Optimism positively influences PreEntrepreneurial Curiosity.

Since optimism was connected to perseverance, effective problem solving, to different kinds of success, and other determinants it is reasonable to predict that it could be connected also to pre-entrepreneurial curiosity measured on a sample of entrepreneurs. This hypothesis answers to a research question if there is the relation between this two entrepreneurship psychology related determinants.

Hypothesis 2: Pre-Entrepreneurial Curiosity positively influences Entrepreneurial Curiosity.

Activities from the pre-entrepreneurial curiosity construct are necessary before a company is open or before an 
entrepreneur starts with a new project. Since entrepreneurial curiosity refers to active planning, defining and realizing of aims in the entrepreneurial process it is logical to predict that these two determinants should be connected. Hypothesis 2 answers to a research question if pre-entrepreneurial curiosity is connected to entrepreneurial curiosity.

\section{Method}

\subsection{Sample and data collection process}

For the purpose of data collection, the questionnaires were sent to entrepreneurs from Slovenia and the USA. The multi-country sample consisted from small and medium size enterprises and control questions in the questionnaire were if respondents are founders or owners who participated in the start-up process of their company.

For the Slovenian sample, the questionnaires were administered in the Slovenian language and for the US sample, the questionnaires were in English language. Slovenian and US entrepreneurs were chosen for current multi-country research because they are countries from the first world and present two similar countries according to current situation on the field of entrepreneurship where economies base mostly on a private ownership, freedom of entrepreneurial initiative and open markets for entrepreneurial activities. Previous research of entrepreneurial curiosity (Jeraj and Antončič, 2013) showed that entrepreneurs from Slovenia and USA are similar according to their specifics related to entrepreneurship, and also according to their entrepreneurial curiosity level. Current paper expands the entrepreneurial curiosity research area from Jeraj and Antončič (2013) who suggested that another future research goal could be to analyse entrepreneurial curiosity in a model: to research the determinants that influence entrepreneurial curiosity. Another reason for joining these two samples was the aim to create more generalized model of optimism and entrepreneurial curiosity on a sample from these countries where the construct of the entrepreneurial curiosity was conceptualized, developed and empirically validated.

Emails with a link to the survey and a specific token for each respondent were sent to 4,000 entrepreneurs in Slovenia and to 5,000 entrepreneurs in the USA who needed approximately 10 minutes to complete the survey. In both countries, email addresses were selected randomly from public registers ${ }^{1}$. The survey consisted from measures of optimism, entrepreneurial curiosity, some demographic questions, and questions of their companies presented more detailed in chapter 5.2 Description of measures. Respondents could not continue on the next page of the online survey if not all questions have been answered so all of the 331 questionnaires that were returned were fulfilled fully.

\subsection{Description of measures}

Optimism was measured using the Life Orientation TestRevised - LOT-R (Scheier et al., 1994). Entrepreneurs were asked to indicate the extent of their agreement with each of the items; how strongly they agree or disagree with the statement on a five level Likert's scale (1974).

\section{Table 1: Optimism measure}

\section{OPTIMISM}

\begin{tabular}{|l|l|}
\hline 1. & In uncertain times, I usually expect the best. \\
\hline 2. & It is easy for me to relax. \\
\hline 3. & If something can go wrong for me, it will. \\
\hline 4. & I am always optimistic about my future. \\
\hline 5. & I enjoy my friends a lot. \\
\hline 6. & It is important to me to keep busy. \\
\hline 7. & I hardly ever expect things to go my way. \\
\hline 8. & I do not get upset too easily. \\
\hline 9. & I rarely count on good things to happen to me. \\
\hline 10. & $\begin{array}{l}\text { Overall, I expect more good things to happen to me } \\
\text { than bad. }\end{array}$ \\
\hline
\end{tabular}

Italic: These items were reverse scored before scoring and analyses.

According to Jeraj (2014) Pre-Entrepreneurial Curiosity measure is composed of entrepreneurial curiosity items that focus to pre-business activities. These activities are necessary before a company is opened or before an entrepreneur starts with a new project. Entrepreneurs had to indicate for each of the statements related to pre-entrepreneurial curiosity how often does a particular activity occur in their life by circling the number of frequency of the occurrence from " 1 " - the activity never occurs to " 7 " - it always occurs.

\section{Table 2: Pre-Entrepreneurial Curiosity measure}

\section{PRE- ENTREPRENEURIAL CURIOSITY}

1. While doing market research, I focus on the work so much that I lose track of time.

2. When I notice an abandoned building, I think about what business potential it represents for me.

3. It bores me to always watch the same products; therefore, I think about improving and offering them to the market. 
Entrepreneurial curiosity measure in this research includes some other variables from an entrepreneurial curiosity measure (Jeraj, 2014). Entrepreneurial curiosity measure, which refers to active planning and defining of aims in the entrepreneurial process, was consisted from five items. For each of the statements related to entrepreneurial curiosity, entrepreneurs had to indicate how strongly they personally agree or disagree with the statement. "l" indicated that they strongly disagree, and "7" indicated that they strongly agree with the statement.

\section{Table 3: Entrepreneurial Curiosity measure}

\section{ENTREPRENEURIAL CURIOSITY}

1. I explore new things that could create additional profit.

2. I am interested in other entrepreneurs' interests.

3. In entrepreneurial work, I am mostly interested in competition.

4. In my business, I must have information about marketing that is as complete as possible.

5. I am able to create added value from my observations of the environment.

\section{Results}

The sample consisted of 237 (71.6\%) male and 93 (28.1\%) female respondents (one person did not give their gender, as it was possible not to provide an answer in that particular question). The average age of the respondents was 47.85 years. $47.7 \%$ of respondents came from Slovenia and 52.3\% of them from the USA.

In the Table 4 is the sample structure regarding to the respondents' companies by sector, sample structure in regard to the age of the company is in the Table 5, number of employees is in the Table 6, and sample structure by total sales in year 2011 in USD in the Table 7.

Table 4: Sample structure in regard to the respondents' companies by sector

\begin{tabular}{|l|c|c|}
\hline & Frequency & Percent \\
\hline $\begin{array}{l}\text { Banking, investment, } \\
\text { insurance }\end{array}$ & 29 & 8,8 \\
\hline $\begin{array}{l}\text { Manufacturing indus- } \\
\text { trial goods }\end{array}$ & 31 & 9,4 \\
\hline $\begin{array}{l}\text { Retail or wholesale } \\
\text { trade }\end{array}$ & 36 & 10,9 \\
\hline Construction & 38 & 11,5 \\
\hline $\begin{array}{l}\text { Engineering, research } \\
\text { \&amp; development }\end{array}$ & 17 & 5,1 \\
\hline
\end{tabular}

\begin{tabular}{|l|c|c|}
\hline $\begin{array}{l}\text { Transportation or pub- } \\
\text { lic utilities }\end{array}$ & 9 & 2,7 \\
\hline Consumer services & 25 & 7,6 \\
\hline Mining, extraction, oil & 7 & 2,1 \\
\hline Tourism & 21 & 6,3 \\
\hline $\begin{array}{l}\text { Manufacturing con- } \\
\text { sumer goods }\end{array}$ & 12 & 3,6 \\
\hline $\begin{array}{l}\text { Management consult- } \\
\text { ing \&amp; business } \\
\text { services }\end{array}$ & 41 & 12,4 \\
\hline Other & 65 & 19,6 \\
\hline Total & 331 & 100,0 \\
\hline
\end{tabular}

Table 5: Sample structure in regard to the age of the company (in years)

\begin{tabular}{|l|c|c|}
\hline & Frequency & Percent \\
\hline $0-1$ & 5 & 1,5 \\
\hline $2-5$ & 37 & 11,2 \\
\hline $6-10$ & 43 & 13,0 \\
\hline $11-20$ & 114 & 34,4 \\
\hline $21-50$ & 99 & 30,5 \\
\hline more than 50 & 33 & 10,0 \\
\hline Total & 331 & 100,0 \\
\hline
\end{tabular}

Table 6: Number of employees (full time equivalent)

\begin{tabular}{|l|c|c|}
\hline & Frequency & Percent \\
\hline 0 & 1 &, 3 \\
\hline $0-10$ & 163 & 49,2 \\
\hline $11-50$ & 74 & 22,4 \\
\hline $51-100$ & 47 & 14,2 \\
\hline $101-250$ & 13 & 3,9 \\
\hline $251-500$ & 15 & 4,5 \\
\hline $501-1.000$ & 9 & 2,7 \\
\hline more as 1.000 & 9 & 2,7 \\
\hline Total & 331 & 100,0 \\
\hline
\end{tabular}

Table 7: Sample structure by total sales in year 2011in USD

\begin{tabular}{|l|c|c|}
\hline & Frequency & Percent \\
\hline 0 & 1 &, 3 \\
\hline under $\$ 50.000$ & 17 & 5,1 \\
\hline$\$ 50.000-100.000$ & 27 & 8,2 \\
\hline$\$ 100.000-250.000$ & 41 & 12,4 \\
\hline$\$ 250.000-500.000$ & 46 & 13,9 \\
\hline
\end{tabular}




\begin{tabular}{|l|r|r|}
\hline$\$ 500.000-1.000 .000$ & 27 & 8,2 \\
\hline$\$ 1.000 .000-2.000 .000$ & 39 & 11,8 \\
\hline$\$ 2.000 .000-5.000 .000$ & 34 & 10,3 \\
\hline $\begin{array}{l}\$ 5.000 .000- \\
25.000 .000\end{array}$ & 55 & 16,6 \\
\hline$\$ 25.000 .000$ or more & 44 & 13,3 \\
\hline Total & 331 & 100,0 \\
\hline
\end{tabular}

Exploratory factor analysis (EFA) was conducted for both, the Slovenian sample and the US sample together. With joined samples, I wanted to show the relations between all studied entrepreneurial determinants among entrepreneurs from two countries and not the differences between samples.

A method to test the model by applying structural equation modelling is present in continuation. This operation was made by building a model in Lisrel 8.80 , which is an analytical statistics program. Results of structural equation modelling based on the whole sample $(\mathrm{n}=331)$ are displayed in Figure 1 and the T-test values in Figure 2.

For the purpose of finding results of multi-country empirical validation was used a combination of exploratory (EFA) and confirmatory methods (CFA - all the variables were included to the structural equation model) with the goal to develop a model which complement theoretical predisposition and fit the data (Černe et al., 2013; Marič et al., 2013).

Hypothesis 1 was: Optimism influences positively PreEntrepreneurial Curiosity.

As seen on Figure 1 higher levels of optimism lead to higher levels of pre-entrepreneurial curiosity; influence is moderate $(0.30)$, positive and statistically significant $(\mathrm{t}$ $=3.76$; as seen on Figure 2). This finding is in support of Hypothesis 1.

Hypothesis 2 was: Pre-Entrepreneurial Curiosity influences positively Entrepreneurial Curiosity

As seen on Figure 1 higher levels of pre-entrepreneurial curiosity lead to higher levels of entrepreneurial curiosity; influence is high (0.63), positive and statistically significant $(\mathrm{t}=6.29$; as seen on Figure 2). This finding is in support of Hypothesis 2.

The fit indices of the structural model (Figure 1 and Figure 2) present a good model fit, which is indicated by the values of $\chi 2 / \mathrm{df}=2.949$, RMSEA $=0.077$, NFI $=0.81$, CFI $=$ $0.87, \mathrm{RMR}=0.091$, and GFI $=0.88$. The hypotheses were defined to test the relations between the constructs in this model; both two show a statistical significance according to the t-test values whereas the whole model shows statistical significance of $\mathrm{P}$-value $=0.0000$.

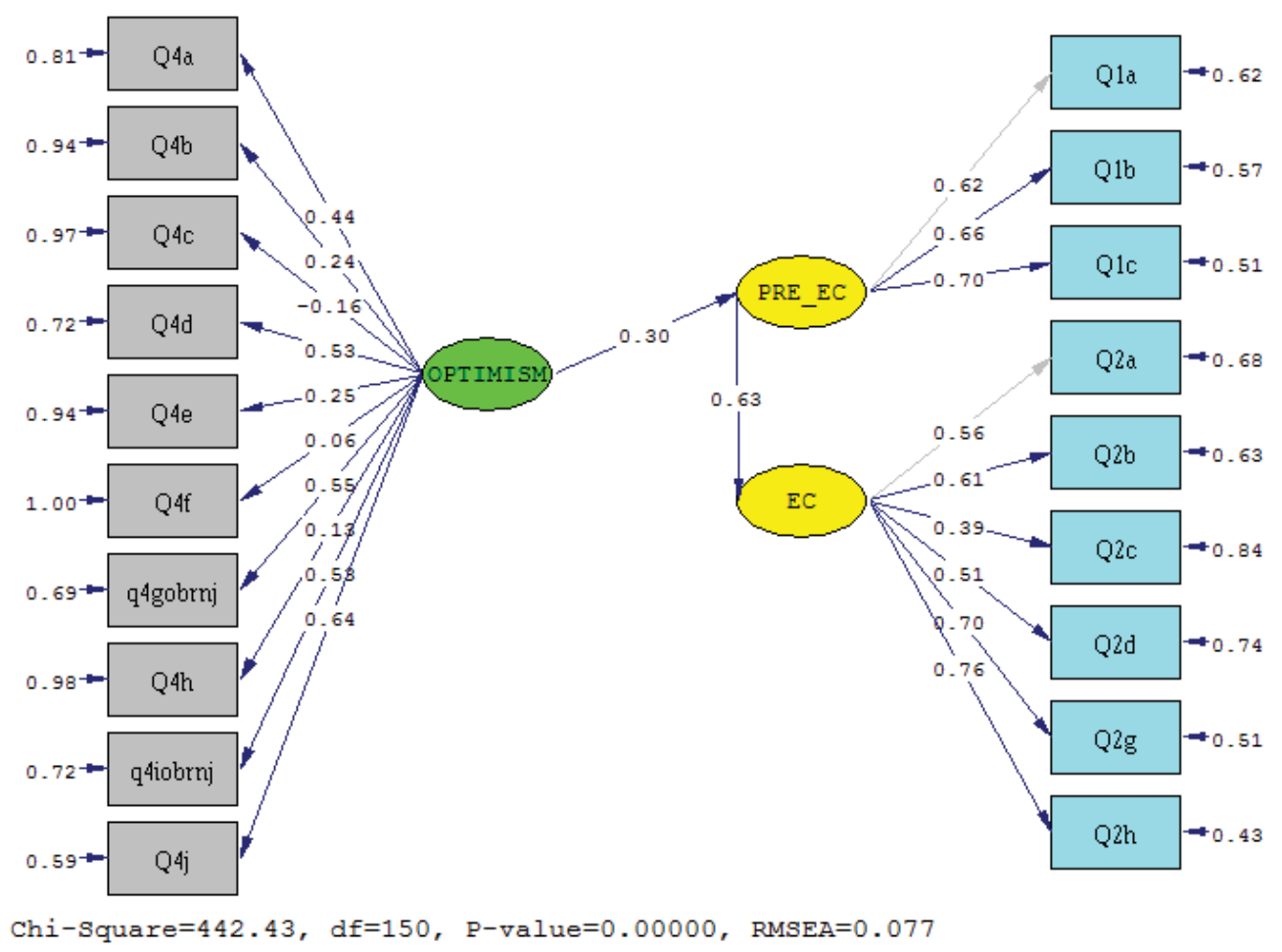

Figure 1: Standardized solution of the tested model 


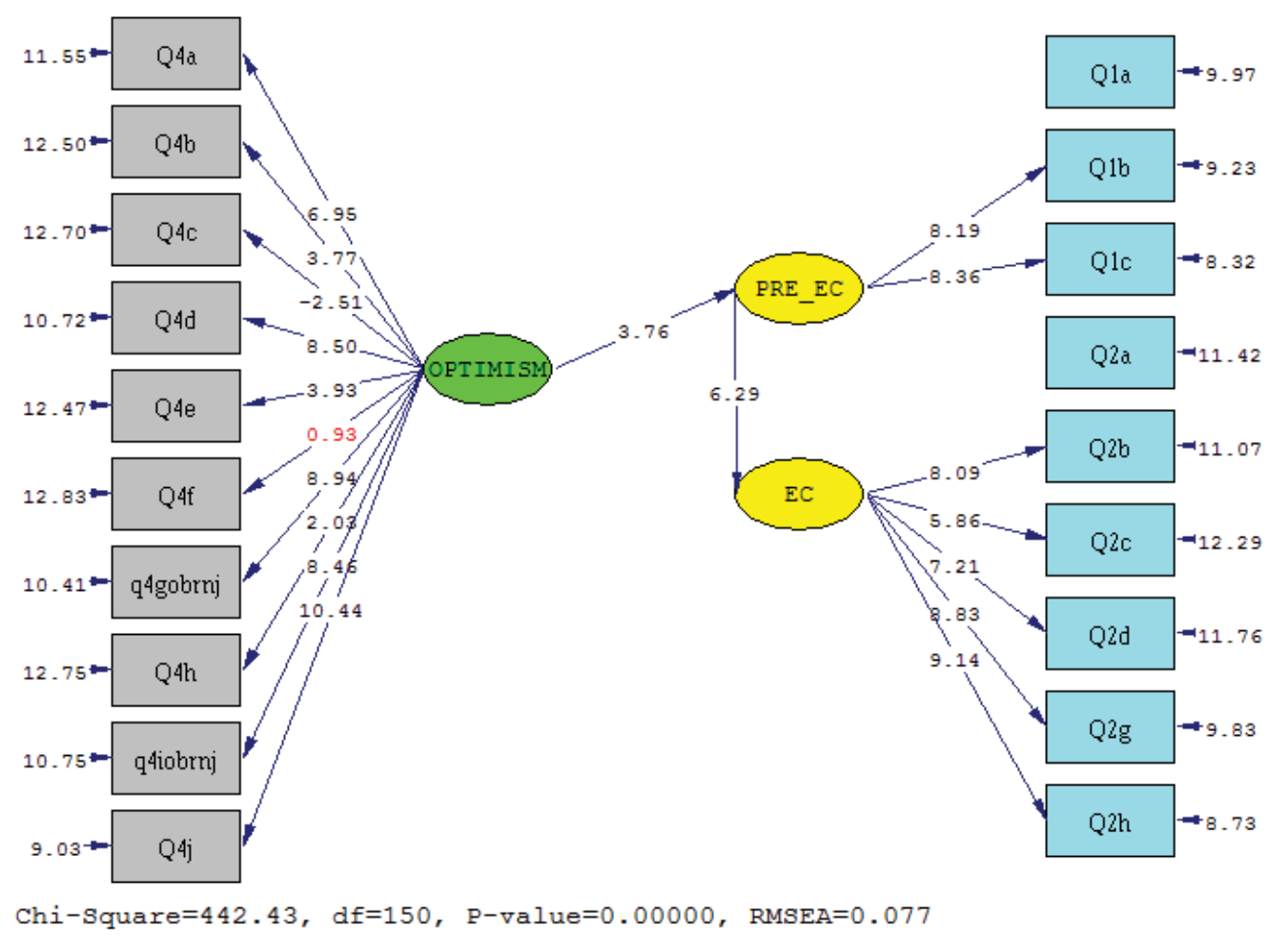

Figure 2: T-values for the tested model

\section{Discussion}

The results of this study indicate that at the frame of entrepreneurs, psychology optimism is important for preentrepreneurial curiosity and pre-entrepreneurial curiosity is important for entrepreneurial curiosity. This result is not surprising since already Hmieleski and Carr (2007) argued that the entrepreneurship literature on optimism has provided strong support for concluding that entrepreneurs tend to be, on average, more optimistic than other people are.

The fact is that not all entrepreneurs are optimistic all the time, especially given the volatile economic and financial situations such as we are dealing with today (Liang and Dunn, 2010). Since entrepreneurial curiosity is oriented to entrepreneurship investigation, to learn tasks related to entrepreneurship and incorporate new experiences in order to improve business; it is an interest in novelties or observations of society; and a tendency to search for answers that indicate which demands should be met it is important determinant affecting entrepreneurs (Jeraj, 2014). In that manner optimism is an important factor of entrepreneurial psychology for boost the level of pre and entrepreneurial curiosity in order to be more prepared for current entrepreneurial tasks and future strategic planning. When an entrepreneur fells optimistic, his effort in gathering data (entrepreneurial curiosity) is on higher level and that could represent a dif- ference between success of his company in regard to the competition.

Particularly important within the context of entrepreneurship is the finding that optimists, as opposed to pessimists, often enjoy experiencing various forms of adversity (Scheier et al., 2001). From that manner, optimism on a too high level could be in some cases negative for entrepreneurs. I assume that the relatively high level of optimism is important and positive for entrepreneurs and for influence on their level of entrepreneurial curiosity.

\section{Contribution, implications for theory, research, practice and economic policy}

The contribution of this study is manifold. From the theoretical view, a literature gap on the field of optimism and entrepreneurial curiosity combined has been investigated and fulfilled. I established a structural equation model with optimism and entrepreneurial curiosity in two forms. To my knowledge, this is the first model combining these factors.

Another study can be done with new constructs in structural equation model and tested with optimism and entrepreneurial curiosity. Based on upper literature review and results of this study it is reasonable to predict that indi- 
viduals with higher level of optimism and entrepreneurial curiosity will be more successful in entrepreneurship from those that lack these two constructs.

From the view of practice and economic policy implications of this study are seen as the platform on which the policy makers can test individuals according to their level of optimism and entrepreneurial curiosity and motivate more entrepreneurial perspective ones to become active in the entrepreneurship process. Entrepreneurs exhibit a stronger optimistic disposition compared to employed individuals (Dushnitsky, 2010) and individuals with higher levels of entrepreneurial curiosity are successful in the entrepreneurship, regarding to their company's growth (Jeraj, 2014).

With successful entrepreneurs and their enterprises, the society can invest money, time and other variables more efficiently and enable long-term growth and reduction of unemployment.

\section{Limitations and future research opportunities}

The first limitation could be the fact that the survey was made only on the sample of Slovenian and USA entrepreneurs. Since the entrepreneurial activity today is similar in Slovenia and USA (Kelley et al., 2013) there is a possibility that the results could not be applied to all countries where the entrepreneurial climate is different (countries in development and others). However, in the same point that limitation represent also future research opportunity. Next research could be done on a sample of entrepreneurs from countries in development to compare results from this study. The results from countries in the development could show that optimism and entrepreneurial curiosity are not connected and important for entrepreneurial success since entrepreneurs need other variables to succeed, as strong relations with the government, strong social networks and others.

This study reveals that both optimism and entrepreneurial curiosity are important for entrepreneurs. Based on reason findings optimism could be also negative determinant for entrepreneurs. Liang and Dunn (2010) summarized that optimism is also characterized as a negative factor in entrepreneurship: being over confident and unrealistically optimistic drive entrepreneurs to over-estimate the odds they will succeed (Baron and Shane, 2005; Hey, 1984).

Further Petrakis (2005) argues optimism has also been linked to the risk tolerance and high expectations. Optimists often deluded themselves into becoming entrepreneurs with high risks of failure (De Meza and Southey, 1996). Another experiment conducted by Coelho and De Meza (2006) discovered that irrational expectations (also interpreted as unrealistic optimism) led entrepreneurs to behave in ways that are contrary to their interests and resulted in a loss of well-being.
On the one hand, the theory describes optimism mostly as a positive determinant for entrepreneurs but on the other hand, also negative consequences could be found based on too high level of optimism among entrepreneurs. Future research opportunity here could be a research where the scientists would define the optimal level of optimism for entrepreneurs. That would be the level where entrepreneurs are open for entrepreneurial related activities but not to open to avoid unverified decisions.

\section{Conclusion}

This research revealed that both determinants optimism and entrepreneurial curiosity are important for entrepreneurs. Further, it was proven based on the results of structural equation modelling that optimism influences positively preentrepreneurial curiosity and that pre-entrepreneurial curiosity influences positively entrepreneurial curiosity.

Current results together with the literature review show that entrepreneurs use these two determinants by their activities to raise the rate of their success. Both determinants present promising research field for future studies.

Optimism is a positive influence on entrepreneurs but in some cases, optimism can be also a negative influence on them and on their entrepreneurial behaviour. Entrepreneurial curiosity on the other site is a psychology-entrepreneurial construct that influences entrepreneurs in the positive way. Based on those findings I think it is important to have both, optimism and entrepreneurial curiosity in a relatively high level in order to gain optimal results.

\section{References}

Ajpes. (2014). Ajpes Agencija Republike Slovenije za javnopravne evidence in storitve. Retrieved January 14, 2013 from http:// www.ajpes.si/

Amabile, T. M. (1997). Entrepreneurial creativity through motivational synergy. The Journal of Creative Behavior, 31(1), 18-26, http://dx.doi.org/10.1002/j.2162-6057.1997.tb00778.x

Arabsheibani, G., de Meza, D., Maloney, J., \& Pearson, B. (2000). And a vision appeared unto them of a great profit: evidence of self-deception among the self-employed. Economics Letters, 67(1), 35-41, http://dx.doi.org/10.1016/ S0165-1765(99)00242-6

Audretsch, D. B., Carree, M. A., \& Thurik, A. R. (2001). Does entrepreneurship reduce unemployment? (No. 01-074/3). Tinbergen Institute Discussion Paper. Retrieved May 12, 2014 from https://www.econstor.eu/dspace/bitstream/10419/85927/1/01074.pdf

Autio, E. (2007). GEM 2007 Report on high-growth entrepreneurship. London: GERA.

Baron, R. \& Shane. S. (2005). Entrepreneurship: A Process Perspective, 1st Edition, Mason, Ohio: South-Western Publishing, p. 60. 
Bengtsson, O., \& Ekeblom, D. (2014). The Bright but Right View? A New Type of Evidence on Entrepreneurial Optimism (February 19, 2014). IFN Working Paper No. 1008. Retrieved June 25, 2014 from http://ssrn.com/abstract=2398954

Bizi. (2014). Poslovni imenik Bizi. Retrieved January, 14, 2013 from http://www.bizi.si/

Busenitz, L., \& Barney, J. (1997). Differences between entrepreneurs and managers in large organizations: Biases and heuristics in strategic decision-making. Journal of Business Venturing, 12(1), 9-30, http://dx.doi.org/10.1016/S08839026(96)00003-1

Busenitz, L. W., West Iii, G. P., Shepherd, D., Nelson, T., Chandler, G. N., \& Zacharakis, A. (2003). Entrepreneurship Research in Emergence: Past Trends and Future Directions. Journal of Management, 29(3), 285-308, http://dx.doi.org/10.1016/ S0149-2063(03)00013-8

B2B E-Mail Databases. (2014). B2B E-Mail Databases. Retrieved in January, 2013 from http://b2b-databases.com/

Camerer, C., \& Lovallo, D. (1999). Overconfidence and excess entry: An experimental approach. American Economic Review, 89(1), 306-318, http://dx.doi.org/10.1257/aer.89.1.306

Cassar, G. (2010). Are individuals entering self-employment overly optimistic? An empirical test of plans and projections on nascent entrepreneur expectations. Strategic Management Journal, 31(8), 822-840, http://dx.doi.org/10.1002/smj.833

Černe, M., Dimovski, V., Marič, M., Penger, S., \& Škerlavaj, M. (2013). Congruence of leader self-perceptions and follower perceptions of authentic leadership: understanding what authentic leadership is and how it enhances employees> job satisfaction. Australian journal of management. Published online before print September 24, 2013, http://dx.doi. org $/ 10.1177 / 0312896213503665$

Chang, E. C., \& Farrehi, A. S. (2001). Optimism/pessimism and information-processing styles: can their influences be distinguished in predicting psychological adjustment? Personality and Individual Differences, (4)31, 555-562, http://dx.doi. org/10.1016/S0191-8869(00)00159-8

Coelho, M., \& De Meza, D. (2006). Self-Deception, Self-Selection, Self-Destruction: An Experimental Investigation of Adverse Selection, London School of Economics. Retrieved April 4, 2014 from http://cebr.dk/upload/demeza-001.pdf

Cooper, A., Woo., C., \& Dunkelberg, W. (1988). Entrepreneurs' perceived chances for success. Journal of Business Venturing, 3(2), 97-108, http://dx.doi.org/10.1016/0883-9026(88)900201

Crane, F., \& Crane, E. (2007). Dispositional optimism and entrepreneurial success. The Psychologist- Manager Journal, 10(1), 13-25, http://dx.doi.org/10.1080/10887150709336610

De Meza, D., \& Southey, C. (1996). The Borrower's Curse: Optimism, Finance and Entrepreneurship, The Economic Journal, 106, March, Cambridge, MA, p. 385.

Dees, J. G. (1998). The meaning of social entrepreneurship. Comments and suggestions contributed from the Social Entrepreneurship Funders Working Group, 1-5, retrieved April 10, 2013 from http://www.google.si/url?sa=t\&rct=j\&q $=\&$ esrc $=$ s\& $\&$ source $=$ web $\& c d=1 \&$ ved $=0$ CB4QFjAA\&url $=$ http $\% 3 \mathrm{~A} \% 2 \mathrm{~F} \% 2 \mathrm{Fwww}$.caseatduke.org $\% 2 \mathrm{Fdocuments} \% 2 \mathrm{Fdees}$ sedef.pdf\&ei=bNqjU_ziO5PX7AaIt4GoCw\&usg=AFQjCN FtTKSFhxk711H-hZ8İbAYEG74KiA\&bvm=bv.69411363,d. bGQ
Doepke, M., \& Zilibotti, F. (2013). Culture, Entrepreneurship, and Growth. NBER Working Paper, (w19141), http://dx.doi. org/10.1016/B978-0-444-53538-2.00001-0

Douglas, E. J. (2012). Reconstructing entrepreneurial intentions to identify predisposition for growth. Journal of Business Venturing, 28(5), 633-651, http://dx.doi.org/10.1016/j.jbusvent.2012.07.005

Dushnitsky, G. (2010). Entrepreneurial optimism in the market for technological inventions. Organization Science, 21(1), 150167, http://dx.doi.org/10.1287/orsc.1090.0454

Dyer, W. G., \& Handler, W. (1994). Entrepreneurship and family business: Exploring the connections. Entrepreneurship Theory and Practice, 19, 71-83.

Fraser, S., \& Greene, F. (2006). The effects of experience on entrepreneurial optimism and uncertainty. Economica, 73(290), 169-192, http://dx.doi.org/10.1111/j.1468-0335.2006.00488.x

Gartner, W. B. (1988). Who is an entrepreneur? Is the wrong question. American Journal of Small Business, 12(4), 11-32, http://dx.doi.org/10.1.1.371.5038

Henderson, R., \& Robertson, M. (2000). Who wants to be an entrepreneur? Young adult attitudes to entrepreneurship as a career. Career Development International, 5(6), 279-287, http://dx.doi.org/10.1108/13620430010373755

Hey, J. (1984). The Economics of Optimism and Pessimism, KTKLOS, Vol. 37, Fasc. 2. University of York, England, p. 204.

Hmieleski, K. M. \& Carr, J. C. (2007). The Relationship between Entrepreneur Psychological Capital and Well-Being. Babson College Entrepreneurship Research Conference (BCERC) 2007; Frontiers of Entrepreneurship Research 2007. Available at SSRN: http://ssrn.com/abstract=1064021

James, N., \& Gudmundsson, A. (2012). The language of optimism: how entrepreneurs sell the sizzle in business plan offer documents. In 57th International Council for Small Business World Congress 2012: Leading from the Edge, 10 - 13 June 2012, Wellington, New Zealand. 1-19.

Jensen, S. M., \& Luthans, F. (2006). Relationship between Entrepreneurs' Psychological Capital and Their Authentic Leadership. Journal of Managerial Issues, 18(2), 254-273.

Jeraj M. (2014). Entrepreneurial Curiosity: Construct Development, Determinants and Outcomes. Doctoral Dissertation. University of Ljubljana: Faculty of Economics.

Jeraj, M., \& Antončič, B. (2013). A Conceptualization of Entrepreneurial Curiosity and Construct Development: a Multi-Country Empirical Validation. Creativity Research Journal, 25(4), 426-435, http://dx.doi.org/10.1080/1040041 9.2013 .843350

Jeraj, M. \& Marič, M. (2013a). Relation between Entrepreneurial Curiosity and Entrepreneurial Self-efficacy: a Multi-Country Empirical Validation. Organizacija, 46(6), 264-273, http:// dx.doi.org/10.2478/orga-2013-0027

Jeraj, M. \& Marič, M. (2013b). Entrepreneurial Curiosity - The New Construct. In High potentials, lean organization, internet of things: proceedings of the 32nd International Conference on Organizational Science Development, March 2014 (289298). Kranj: Moderna organizacija.

Jeraj, M., \& Prodan, I. (2010). Conceptualization of Entrepreneurial Curiosity. In The Advances in Business-Related Scientific Research Conference 2010, September 2010. Olbia, Italy: ABSRJ. 
Jeraj, M. (2012). Toward the new construct; Entrepreneurial Curiosity. V D. Barkovic and B. Runzheimer (ur.), Interdisciplinary research VIII (p. 1043-1055). Opatija: Josip Juraj Strossmayer University in Osijek.

Kelley, D. J., Singer, S., \& Herrington, M. (2012). The global entrepreneurship monitor. 2011 Global Report, GEM 2011, 7.

Koellinger, P. (2008). Why are some entrepreneurs more innovative than others? Small Business Economics, 31(1), 21-37, http://dx.doi.org/10.1007/s11187-008-9107-0

Kreft, S. F., \& Sobel, R. S. (2005). Public policy, entrepreneurship, and economic freedom. Cato Journal, 25(3), 595-616.

Kuratko, D. (2013). Entrepreneurship: Theory, Process, and Practice. Cengage Learning. p.624

Landier, A., \& Thesmar, D. (2009). Financial contracting with optimistic entrepreneurs. Review of Financial Studies, 22(1), 117-150, http://dx.doi.org/10.1093/rfs/hhn065

Liang, C. L., \& Dunn, P. (2010). Entrepreneurial Characteristics, Optimism, Realism and Pessimism: Correlation or Collision? Journal of Business and Entrepreneurship, 22, 1-22.

Liang, K., \& Dunn, J. (2008a). Are Entrepreneurs Optimistic, Realistic, Both or Fuzzy?. Academy of Entrepreneurship, 14(1 \& 2), 51-76.

Liang, K., \& Dunn, P. (2008b). Exploring the Myths of Optimism and Realism in Entrepreneurship Related to Expectations and Outcomes. Journal of Business and Entrepreneurship, 20(1), 1-17.

Likert, R. (1974). A method of constructing an attitude scale. In G. M.Maranell (Ed.), Scaling: A sourcebook for behavioural scientists (pp. 233-243). Chicago: Aldine.

Luthans, F. \& Youssef, C. M. (2004). Human, social, and now positive psychological capital management: Investing in people for competitive advantage. Organizational Dynamics, 33(2), 143-160, http://dx.doi.org/10.1016/j.orgdyn.2004.01.003

Marič, M., Dimovski, V., Djurica, M., Černe, M., \& Đurica, N. (2013). Developing the supervisor ss authentic leadership measure. Technics Technologies Education Management, 8(1), 229-237, ISSN 1840-1503.

Orejudo, S., Puyuelo, M., Fernández-Turrado, T., \& Ramos, T. (2012). Optimism in adolescence: A cross-sectional study of the influence of family and peer group variables on junior high school students. Personality and Individual Differences, (7)52, 812-817, http://dx.doi.org/10.1016/j.paid.2012.01.012

Peterson, C. (2000). The future of optimism. American Psychologist, 55(1), 44-55, http://dx.doi.org/10.1037/0003-066X.55.1.44

Petrakis, P. E. (2005). Risk Perception, Risk Propensity and Entrepreneurial Behavior: The Greek Case. The Journal of American Academy of Business, 7(1), September, Cambridge, p. 237.

Pinfold, J. (2001). The Expectations of New Business Founders. Journal of Small Business Management, 39(3), 279-285, http://dx.doi.org/10.1111/0447-2778.00025

Puri, M., \& Robinson, D. (2006). Who are entrepreneurs and why do they behave that way? Duke University Working Paper.

Renner, B. (2006). Curiosity about People: The Development of a Social Curiosity Measure in Adults. Journal of Personality Assessment, 87(3), 305-316, http://dx.doi.org/10.1207/ s15327752jpa8703 11

Román, C., Congregado, E., \& Millán, J. M. (2013). Start-up incentives: entrepreneurship policy or active labour market programme?. Journal of Business Venturing, 28(1), 151-175, http://dx.doi.org/10.1016/j.jbusvent.2012.01.004
Sarasvathy, S. D., Menon, A. R., \& Kuechle, G. (2013). Failing firms and successful entrepreneurs: Serial entrepreneurship as a temporal portfolio. Small Business economics, 40(2), 417434, http://dx.doi.org/10.1007/s11187-011-9412-x

Scarpetta, S., Hemmings, P., Tressel, T., \& Woo, J. (2002). The Role of Policy and Institutions for Productivity and Firm Dynamics: Evidence From Micro and Industry Data, OECD Economics Department Working Papers, No. 329, OECD Publishing, http://dx.doi.org/10.1787/547061627526

Scheier, M.F., Carver, C. S., \& Bridges, M.W.(1994). Distinguishing optimism from neuroticism (and trait anxiety, self-mastery, and self-esteem): A reevaluation of the Life Orientation Test. Journal of Personality and Social Psychology, 67(6): 10631078, http://dx.doi.org/10.1037/0022-3514.67.6.1063

Scheier, M. F., Carver, C. S., \& Bridges, M. W. (2001). Optimism, pessimism, and psychological wellbeing. In E. C. Chang (Ed.), Optimism \& Pessimism: Implications for Theory, Research, and Practice (pp. 198-216). Washington D. C.: American Psychological Association.

Schneider, M. (2005). A Measure of Entrepreneurial Risk Preference and Optimism Using Field Experiments, Master Thesis, Department of Economics, University of Central Florida, Orlando, Florida.

Shane, S., Locke, E. A., \& Collins, C. J. (2003). Entrepreneurial motivation. Human Resource Management Review, 13(2), 257-279, http://dx.doi.org/10.1016/S1053-4822(03)00017-2

Thai, M. T. T., \& Turkina, E. (2013). Macro-level determinants of formal entrepreneurship versus informal entrepreneurship. Journal of Business Venturing, 29(4), 490-510, http://dx.doi. org/10.1016/j.jbusvent.2013.07.005

Thurik, R. \& Wennekers, S. (2004). Entrepreneurship, small business and economic growth. Journal of Small Business and Enterprise Development, 11(1), 140-149, http://dx.doi. org/10.1108/14626000410519173

Trevelyan, R. (2008). Optimism, overconfidence and entrepreneurial activity. Management Decision, 46(7), 986-1001, http://dx.doi.org/10.1108/00251740810890177

Ucbasarana, D., Westhead, P., Wright, M., \& Flores, M. (2010). The nature of entrepreneurial experience, business failure and comparative optimism. Journal of Business Venturing, 25(6), 541-555, http://dx.doi.org/10.1016/j.jbusvent.2009.04.001

Ulhøi, J. P. (2005). The social dimensions of entrepreneurship. Technovation, 25(8), 939-946, http://dx.doi.org/10.1016/j. technovation.2004.02.003

Van Stel, A., Carree, M. \& Thurik, R. (2005). The effect of entrepreneurial activity on national economic growth. Small Business Economics, 24(3), 311-321, http://dx.doi.org/10.1007/s11187005-1996-6

Wenglert, L. \& Rosén, A. S. (2000). Measuring optimismpessimism from beliefs about future events. Personality and Individual Differences, 28(4), 717-728, http://dx.doi. org/10.1016/S0191-8869(99)00133-6

Wennekers, S., \& Thurik, R. (1999). Linking entrepreneurship and economic growth. Small Business Economics, 13(1), 27-56, http://dx.doi.org/10.1023/A:1008063200484

York, J. G., \& Venkataraman, S. (2010). The entrepreneurenvironment nexus: Uncertainty, innovation, and allocation. Journal of Business Venturing, 25(5), 449-463, http://dx.doi. org/10.1016/j.jbusvent.2009.07.007 
Mitja Jeraj, Ph.D. is a researcher in the field of entrepreneurship, management, and organizational sciences. His main research interests include entrepreneurship as a broad field of research, entrepreneurial curiosity and other entrepreneurial personalities, relations between entrepreneurship and economic growth, relations between entrepreneurship and unemployment, connection between entrepreneurship and development of sport etc. His research focuses also on management at small and medium enterprises, on cost management and on development of the organization over the time. He has authored and co-authored and present papers on conferences and published papers in scientific journals. 